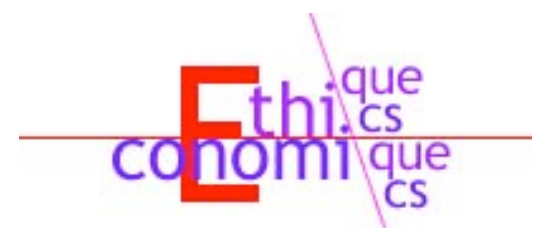

\title{
What can the Stakeholder Theory Learn from Enron? ${ }^{1}$
}

\author{
By/Par $\quad$ Wayne Norman \\ McConnell Professor of Business Ethics \\ Département de philosophie \\ Université de Montréal \\ w.norman@umontreal.ca
}

\section{AbSTRACT:}

Roughly speaking, Enron has done for reflection on corporate governance what AIDS did for research on the immune system. So far, however, virtually all of this reflection on and subsequent reform of governance has come from those with a stake in the success of modern capitalism. This paper identifies a number of governance challenges for critics of capitalism, and in particular for those who urge corporations to voluntarily adopt missions of broader social responsibility and equal treatment for all stakeholder groups. I argue that by generally neglecting the governance relation between shareholders and senior managers, stakeholder theorists have underestimated the way in which shareholder-focused governance can be in the interests of all stakeholder groups. The enemy, if you will, is not capitalists (shareholders), but greedy, corrupt or incompetent managers. A second set of governance challenges for stakeholder theorists concerns their largely untested proposals for governance reforms that would require managers to act in the interests of all stakeholders and not just shareholders; in other words to treat shareholders as just another stakeholder group. I suggest that in such a governance regime it may be almost impossible to hold managers accountable to anyone - just as it was when state-owned enterprises were given "multi-stakeholder" mandates in the 1960s and 1970s.

\footnotetext{
${ }^{1}$ I am grateful for criticisms and suggestions from Jocelyn Maclure, Caroline Allard, Axel Gosseries and the referees from Éthique-Économique. I owe a special debt to Joseph Heath with whom I collaborated on a much longer article covering similar themes (see note 16, below).
} 
Those with a direct stake in the success of capitalism - the 'Right', if you will - reacted quickly to some of the challenges posed by the scandals of the 'Enron era'. Their favourite weekly magazines, like The Economist and Business Week, ran a string of feature investigations and cover stories with titles like "American Capitalism Takes a Beating", and "The Crisis in Corporate Governance". And a number of specific legal and regulatory changes designed to prevent further scandals ensued. I will argue that critics of capitalism the 'Left', if you will - have at least as much to learn from the challenges of governance posed by these scandals. There is little evidence that this learning has yet begun.

\section{WHAT'S LEFT?}

Let us pause briefly to reflect on the nature of "the left" and its contemporary critique of capitalism. Of course, the nineteenth-century labels of "left" and "right" are now more likely to obscure rather than clarify our understanding of contemporary political movements. It used to be easy: those on the left called for less (or even the abolition of) private enterprise and more "state ownership of the means of production"; and those on the right called for the reverse, that is, more private enterprise and smaller government. By the 1970s, for reasons we will discuss later, the trend for more and more "nationalization" of industry began to slow and reverse through most of the developed world. The wave of nationalizations was followed in the 1980s and 1990s by a wave of privatizations, in states run by conservative and socialist governments alike.

For various reasons, which differed somewhat from country to country, it became increasingly difficult for the left to make the case that state-owned industries were in the public interest. Sometimes this was because of the manifest inefficiencies of SOEs compared with their rivals in the private sector (e.g., the products and business practices of, say, airlines and automobile manufacturers in the public and private sectors could be compared directly. $)^{2}$ In other cases there was clearly a public backlash to sometimes frequent or extended strikes that would shut down state-owned monopolies. ${ }^{3}$ When the prospect of extending the policy of nationalisation receded, many on the left fell back on demands for ever-greater regulation of private (and public) industries; principally to counter what economists call the "negative externalities" of businesses. These regulations, which had evolved throughout the $20^{\text {th }}$ century, aimed to increase safety for workers and consumers, as well as to curb pollution, to increase the bargaining power of unions, and to protect employees from lay-offs, poverty wages, and discrimination. But in time it also became difficult to win public debates for more regulation, in part because globalization would seem

\footnotetext{
${ }^{2}$ For the economics of such comparisons, see A. Boardman and A. Vining, 'Ownership and Performance in Competitive Environments: A Comparison of the Performance of Private, Mixed, and State-Owned Enterprises,' Journal of Law and Economics, 32: 1-33; and J. Stiglitz, Whither Socialism? Cambridge, MA: MIT Press, 1996.

${ }^{3}$ See, e.g., A. Ferner, Governments, Managers and Industrial Relations, Oxford: Basil Blackwell, 1988.
} 
to place one's own businesses at a disadvantage in the global marketplace if they are saddled with more rigorous regulations. Business throughout the developed world remains heavily regulated, but the 1980s and 1990s saw some loosening of regulations protecting unions, as well as a levelling out of controls on pollution. ${ }^{4}$ Again, this softening of the interventionist state was initiated by governments historically associated with both the right and the left.

By the 1990s the efforts of many activists on what we might still loosely call "the left" were evolving in several directions. For one thing, they were less likely to press demands for either nationalization or regulation (even if this was what they would have preferred). Indeed, they were less likely in general to focus their energies on the activities of political parties or governments. Instead the focus for many became the reform of businesses themselves. And their preferred vehicle for pressuring business has shifted from government to non-governmental organisations (NGOs). To put it very plainly, the principle activity of many critics of modern capitalism has been to try to convince or "to shame" individual companies into accepting voluntary constraints on their activities. In place of the language of socialism and class warfare we are much more likely now to hear criticisms and recommendations for businesses voiced in the language of "corporate social responsibility" (CSR), "good corporate citizenship", "sustainable development", and "stakeholder-focussed capitalism".

Of course, this is by no means a fair characterization of all of the intellectual and political currents that continue to identify themselves with 'the left'. There are still unreconstructed socialists, trade-unionists and class-warriors. There are also more radical luck-egalitarians, left-libertarians, and advocates of new schemes of market socialism and basic income. My critique here, however, is directed primarily to the growing crowd identified in the previous paragraph: those whose rhetoric and political pressure-tactics are directed primarily to the voluntary reform of the 'behaviour' of profit-seeking businesses in the private sector. What lessons can they draw from the crisis in corporate governance symbolised by the fraud and the collapse of Enron?

\section{CORPORATE SOCIAL RESPONSIBILITY AND STAKEHOLDER THEORY}

Now, for a variety of reasons, much of this new vocabulary of CSR is also being adopted by business leaders themselves as well as by many generally pro-business writers, consultants, and intellectuals. ${ }^{5}$ Sometimes, for sure, this is done by business people as a public relations

\footnotetext{
${ }^{4}$ See, e.g., Lee Preston, Government Regulation and Business Response, JAI Press, 1990; Roland Strausbaugh, Government Regulation in the Business Environment, Dame Publishing, 2002; Simeon Djankov et al., Doing Business in 2004: Understanding Regulation, Washington, DC: World Bank Publications.

${ }^{5}$ For an excellent discussion of the discourse of CSR and "développement durable" in both probusiness and anti-business circles see C. Gendron et J.-P. Revéret, « Les développements durables : voyage au cœur des représentations sociales », Les cahiers du 27 juin, vol. 1, no. 1, février 2003. See
} 
exercise to manage their often-difficult encounters with NGOs and the media. But it is also undoubtedly the case that many pro-business advocates and leaders have a genuine desire to promote more enlightened, socially responsible business practices. Indeed, there are now countless studies that demonstrate a generally positive correlation between profitability and social responsibility in business. ${ }^{6}$ Many advocates try to "sell" CSR to businesses by emphasising this connexion between "doing good" (ethics) and "doing well" (profits) in business.

But although they now share a common vocabulary of CSR, critics and supporters of modern business - the left and the right, if you will - still diverge deeply on just what is actually involved in operating a truly responsible business. To put it most starkly, critics believe that business should voluntarily adopt high standards of environmental controls, as well as more lavish benefits for employees and the communities in which businesses operate even if adopting these commitments will lead to significantly lower profits. Their theory of CSR typically sees the modern corporation as a network of so-called "stakeholders", including the shareholders, senior management, employees, suppliers, customers, and the communities in which the corporation operates. The most radical of these stakeholder theories claim that managers have special obligations to all of these stakeholder groups equally. As Kevin Gibson has articulated this claim, "In the same way that business owes special and particular duties to its investors... it also has different duties to the various stakeholder groups". ${ }^{7}$ One implication of this view is that shareholders are "just another stakeholder group", no more or less important than the others. In the words of Edward Freeman, from the book that is largely credited with launching if not inventing the contemporary language and theory of stakeholder capitalism:

My thesis is that I can revitalize the concept of managerial capitalism by replacing the notion that managers have a duty to stockholders with the concept that managers bear a fiduciary relationship to stakeholders. Specifically I include suppliers, customers, employees, stockholders, and the local community, as well as management in its role as agent for these groups... Each of these stakeholder groups has a right not to be treated as a means to some end, and therefore must participate in determining the future direction of the firm in which they have a stake. ${ }^{8}$

This is radical precisely because corporate law in most countries currently gives shareholders a very special position among stakeholders. (By "corporate law" I mean the part of the law governing ownership and control of corporations, not the much broader array of legislation regulating business activities.) In corporate law throughout most of the Western world

also David Henderson, Misguided Virtue : False Notions of Corporate Social Responisbility, Wellington : New Zealand Business Roundtable, 2001.

${ }^{6}$ For a useful survey and evaluation of the correlation between ethics and profit in business see Lynn Sharp Paine, Value Shift: Why Companies Must Merge Social and Financial Imperatives to Achieve Superior Performance, New York: McGraw-Hill, 2003.

${ }^{7}$ Gibson, Kevin. 2000. "The Moral Basis of Stakeholder Theory," Journal of Business Ethics 26: 245257.

${ }^{8}$ Edward Freeman, Strategic Management: A Stakeholder Approach, Boston: Pitnam, 1984. 
(Germany and Japan being notable exceptions), shareholders are given the right and the power to demand that senior managers of the corporation act in the shareholders' interests by maximizing profits and increasing the value of the shares. ${ }^{9}$ By contrast, many CSR advocates demand that senior managers should work to improve the conditions of all stakeholders, even if this will lower profits and shareholder value. They accept that some profit is necessary to make the organisation sustainable, but that beyond this, shareholders' interests cannot count for any more than the interests of any of the other stakeholders.

This view - which we may dub a "strong CSR programme" - will be my focus for the rest of this article.

\section{THE LESSONS OF ENRON}

The word "Enron" has now come to denote an era as much as a company. The company Enron was the most spectacular example of collapse due to internal fraud or "questionable accounting practices" during a shameful two-year period beginning in late 2001. Other American and international firms implicated in such scandals during this period included AT\&T, AOL-Time Warner, Arthur Andersen (who were Enron's auditors and consultants), WorldCom, General Electric, Tyco, Qwest, Adelphia, Halliburton, Global Crossing, Merrill Lynch, Health South, Royal-Dutch Shell, Parmalat, Nortel, Hollinger, and so on. Of course, there have always been corporate scandals, and there always will be. If we ask critics of capitalism what lessons there are to learn from these scandals of the "Enron era", that is what we are most likely to hear: Enron is symbolic of capitalist greed; it shows that corporations and business people will do anything they can get away with; if government loosens its control even a little over the corporate world business people will do whatever is in their interest with no regard to the public interest. ${ }^{10}$

Needless to say, this is not exactly the post-Enron lesson drawn by those with a vested interest in modern capitalism - including investors, brokerages, pension-fund managers, auditors, stock exchanges, financial regulators, legislators, and so on. Their analysis begins by distinguishing between different elements of what critics often see as a monolithic capitalist corporation. In particular, they distinguish between the (a) shareholders, (b) the Board of Directors that is elected by the shareholders and is supposed to safeguard their interests, ${ }^{11}$ (c) the CEO and other senior executives, and (d) the enduring 'fictitious legal

\footnotetext{
${ }^{9}$ Of course, corporate law varies from country to country, and even from one federal subunit to another in some federations. For a standard American text see, e.g., Stephen Bainbridge, Corporation Law and Economics. New York: Foundation Press, 2002.

${ }^{10}$ This critique is implicit in many post-Enron book titles, such as Arianna Huffington's Pigs at the Trough: How Corporate Greed and Political Corruption Are Undermining America, Crown Publishing, 2003.

${ }^{11}$ In most developed countries, including the United States, the shareholders elect all of the members of the Board. There are some exceptions, including Germany and Japan, where other stakeholder groups, in particular employees, can elect some Board members.
} 
person' that is corporation itself. ${ }^{12}$ Of course, there is no single explanation for all of the Enron-era scandals. Nevertheless, in most of the cases it was not the capitalists (literally the shareholders) or the corporations as such that were to blame, but rather the shareholders' humble and not-so-humble servants: the senior executives, and their watchdogs, the Boards of Directors. The scandals were not "business as usual" under capitalism, but rather a subversion of the basic structure of capitalist governance. It is not that managers were acting in the interest of shareholders to the detriment of all of the other stakeholders. Rather it was typically the case that managers were acting in their own interests, defying their moral and legal duties to shareholders and thereby inflicting tremendous harm on other stakeholders.

The "governance relation" between shareholders and executives had broken down in numerous places: managers were able to enrich themselves in ways that were not in shareholders' interests, and in many cases they were able to conceal these benefits; the Boards of Directors often conspired with the executives (because the executives and their friends sat on the Board, controlling the agenda and directing important committees), or failed to exercise sufficient diligence in monitoring the executives; the shareholders, especially large institutional shareholders, paid insufficient attention to the quality of the Boards and to the reports of external auditors; and the auditors, who are supposed to evaluate management and work in the shareholders' and public's interest, were sometimes more inclined to curry favour with managers who could offer their firms lucrative consulting contracts.

It did not take long for this "mainstream" analysis to translate into some concrete institutional changes in the governance of corporations in the USA. Various public and private regulatory bodies (such as stock exchanges) quickly put into place new rules that would make each of these contributing factors less likely in the future. ${ }^{13}$ Auditing firms have been barred from providing consulting services to their clients; independent directors (ie, those who are not also executives) have been given much more authority on Boards, especially when it comes to hiring, firing and compensating senior executives; and CEOs have been made more legally accountable for the truth and integrity of their financial statements. Many of these changes have also filtered through to other western countries. Although other OECD member-states did not experience the volume of scandals seen in the USA, almost all analysts here recognized that their firms were as vulnerable as those in the USA. $^{14}$

\footnotetext{
${ }^{12}$ On the nature of the fictitious legal personality of corporations, see Bainbridge, Corporation Law and Economics, chapter 1.

${ }^{13}$ The most significant reform was the Sarbanes-Oxley Act of 2002, which toughened rules governing the independence of Boards of Directors and the regulation of the auditing industry.

${ }^{14}$ For a classic study that pre-dates Enron, see Donald Chew, Studies in International Corporate Finance and Governance Systems: Comparisons in the US, Japan and Europe, Oxford: Oxford University Press, 1997.
} 


\section{LESSONS FOR CSR}

What we have just seen is the critique of the Enron era, as well as a set of reforms, from those with a "vested interest in the success of modern capitalism". But what about the critics of modern capitalism? What have supporters of a strong CSR programme thought about this analysis and these developments? The answer, curiously enough, is that they don't seem to have thought much about it so far; at least not in the sense of rethinking any of their own theories of CSR and stakeholder managment.

This is a shame. We now see that pre-Enron theorists of CSR devoted far too little attention to the very important social responsibilities and fiduciary duties of managers to protect the financial integrity of the firm and the interests of shareholders; especially the duty to provide accurate information to the Board and the general public. Again, all of the stakeholders of Enron suffered at the hands of its greedy, and possibly sociopathic, senior officers: thousands of employees lost their jobs and their pensions, small and large investors lost billions of dollars, and customers and suppliers were left with enormous debts when the company could not fulfill its contracts because of sudden bankruptcy. Supporters of strong-CSR had always mentioned duties of companies to their shareholders as one of the many duties to stakeholders. But they had assumed that these duties were already "naturally" taken care of; as if CEOs and wealthy capitalist investors were basically the same class of people (the "bourgeoisie", of course!) who would instinctively look after each others' interests. For this reason, strong-CSR advocates focused almost all of their attention on the question of why and how managers should look after the other stakeholders. Clearly this lack of attention to shareholders by CSR advocates was a mistake. But there are still no signs that this oversight is being reassessed in CSR circles.

When CSR theorists do start thinking more seriously about the idea of governance in the "stakeholder-focused" firm, I think it should lead them to seriously rethink some of their most basic presumptions and commitments. Consider the following two potential governance lessons for CSR: the first one involves understanding the way in which shareholders' interests and those of other stakeholders can often be seen to (or made to) converge; and the second raises concerns about how the accountability of senior managers can be secured if we remove some of the reigns traditionally held by shareholders.

\section{LESSON 1 FOR "STRONG" CSR: TAKING SHAREHOLDERS SERIOUSLY}

First, it might be time to reconsider the idea that shareholders are "just another stakeholder group", no more or less important from the point of view of management priorities than other groups like employees, customers, suppliers and local communities. Of course, it goes without saying that firms cannot be successful in the long term if they neglect any of these key stakeholder groups. But there is a reason for nevertheless believing that there is something special about catering to the interests of shareholders, and this has nothing to do with believing that shareholders as individuals are intrinsically more important. It is not even

Éthique et économique/Ethics and Economics, 2 (2), 2004, 
based on a theory of property rights giving shareholders a special right to treat the firm's resources as their property. Instead it is based purely on governance consideration.

Like many leading stakeholder theorists, most economists and jurists now see the firm as a "nexus of contracts": it is not a "thing" as such that can be owned, but rather just a network of contracts between different individuals and groups. On this view shareholders are not owners of the firm with special rights. They are merely one of many suppliers of capital to the firm. ${ }^{15}$ But what is different about shareholders is that they are the only suppliers of capital who have not contractually agreed to a fixed rate of return on their investment. ${ }^{16}$ They will get a return (in the form of a dividend or a higher resale value for their shares) only if the firm is successful and profitable. Because of this peculiar position and incentive structure, they are a natural group to designate as the "watchdogs" of the managers who actually have control of the firm's resources. The idea here is that if shareholders do their job by installing a strong and competent Board of Directors, then all stakeholders will benefit from a better managed and more successful firm. So in principle there is no reason why supporters of CSR should not find this shareholder-focused model of governance to be something compatible with a socially responsible mission for a firm. This is not to say that all profit-maximising firms will benefit all their stakeholders; but only that if a firm is going to give itself a stakeholder-friendly, CSR mandate and strategy, it could in principle do this better if it nevertheless strengthened the traditional governance role of shareholders. This leads to the second Enron-lesson for stakeholder theorists.

15 For a standard textbook explanation of this theory, see Bainbridge, Corporation Law and Economics. For a more normative analysis see J. Boatright, Ethics in Finance, Oxford: Blackwell, 1999. Note, this view of the corporation has in fact been embraced by leading stakeholder theorists, including the person most responsible for the contemporary currency of the concept of the stakeholders, Edward Freeman.

${ }^{16}$ Of course, this does not mean that shareholders are the only stakeholders who take risks through their involvement with the firm. Indeed, a given shareholder (say, a wealthy investor with only a small part of her wealth invested in the firm) may have much less to lose than most employees if the firm suddenly goes bankrupt. Nevertheless, shareholders are unique in the particular type of risk they undertake. They have the option of putting their money in other safe investments with a fixed rate of return; but instead they trade it for shares which will only give a return if their value rises (because the firm is presumed to have a profitable future) or if there is a dividend payment. To see how peculiar this arrangement is, try to imagine other stakeholders signing a similar contract. E.g., it would be difficult to imagine workers agreeing to get paid only by collecting a percentage of year-end profits; or consultants agreeing to get paid only if their advice led directly to increased profits. 


\section{LESSON 2 FOR STRONG CSR: WORRY ABOUT HOW EXECUTIVES CAN BE HELD ACCOUNTABLE IN THE "STAKEHOLDER-FOCUSED" FIRM ${ }^{17}$}

Again, according to the strong CSR programme, managers should be willing to sacrifice profits for shareholders in order to distribute benefits to other stakeholder groups. As it turns out, this is not nearly as radical and forward-looking an innovation as many stakeholder theorists believe. In fact, we have a wealth of experience in this form of "stakeholder management" in state-owned enterprises (SOEs), especially in the 1960s and 1970s. In that era many national and subnational governments owned companies ranging from airlines, railways, bus companies, to mines, oil, forestry and electricity companies, ports, aircraft and automobile manufacturers, and financial institutions. And in many cases managers of these firms were given multiple objectives. In addition to making profits they were expected to maintain high levels of employment and high wages, to operate in certain less-developed communities, to reduce pollution, to keep prices down, and to provide subsidized products or services to the domestic market. In most cases these experiments in multi-stakeholder management were a disaster - losing spectacular amounts of public money, while often failing to achieve any of the other objectives. ${ }^{18}$ By the late 1970s and 1980s, even before the era of privatization, governments of both the left and the right, in Canada and throughout Europe, withdrew the multi-stakeholder mandates from many state firms and replaced them with the over-riding objective of sustaining profits.

The reason for this change of heart had little to do with the emergence of so-called neoliberal ideology and everything to do with governance and accountability. When senior managers are asked to achieve multiple objectives, they are thereby freed of accountability for achieving any particular objective. In fact, it becomes almost impossible to measure their success or failure; and in such a situation, even the most sincere manager can lose the ability

${ }^{17}$ This "second lesson", and indeed much of the spirit of this article, draws heavily from a much longer article I have co-written with Joseph Heath, "Stakeholder Theory, Corporate Governance and Public Management: What can the history of state-run enterprises teach us in the post-Enron era? Journal of Business Ethics 53, 2004, pp. 247-265.

${ }^{18}$ See, e.g., Boardman and Vining, "Ownership and Performance in Competitive Environments: A Comparison of the Performance of Private, Mixed, and State-Owned Enterprises"; J. Stiglitz, Whither Socialism?, J. Stiglitz et al, The Economic Role of the State, Oxford: Basil Blackwell, 1989; A. Lewin, "Public Enterprise, Purposes and Performance: A Survey of Western European Experience," in W.T. Stanbury and Fred Thompson, Managing Public Enterprises, New York: Prager, 1982; Simon Nora, Rapport sur les enterprises publiques, Paris: La documentation française, 1967. Again, I thank Joseph Heath for steering me toward many of these studies.

Consider just one example of SOE-mismanagement. Ontario Hydro, which at one time was Canada's largest corporation, could not turn a profit in the 1990s despite its status as a monopoly in the Province of Ontario (Canada's richest and most populated province, with nearby export markets in the industrial heartland of the USA). By 1997 it had accumulated a debt of over \$35-billion. Meanwhile, its heavy investment in, and often dangerous mismanagement of, nuclear power was hardly a model of corporate social responsibility. See D. W. Conklin and T. Hunter, "Ensuring the successful privatization of Ontario Hydro", Ivey Business Journal, July/August 2001. 
to manage effectively. Of course, it also provides a license for the less-than-sincere manager to abuse the lack of accountability by running the organization in ways that benefit himself and his cronies rather than the general public. Like the senior executives in the Enron-era scandals, the most corrupt or incompetent managers of SOEs were able to exploit the lack of accountability and oversight in their governance relation to their shareholders (in the case of SOEs, the shareholders are the government, and ultimately the citizens).

One of the most recent examples of a public-spirited SOE switching from a CSR to a profitmaximising mandate is the Caisse de dépôt et placement (CDP) in Quebec. From its founding by a progressive government in 1965, the CDP had operated with a multi-objective mandate. It was supposed to make a good return on investment of pension funds from public employees and others; but it was also supposed to be an engine for developing key sectors of the Quebec economy. (As I understand it, the CDP was never mandated to engage in "socially responsible investing" as that is now typically understood in CSR circles.) In the reforms that followed the $\$ 8.55$-billion loss it reported in 2002, as well as some particular investment scandals (such as one involving Montréal Mode which was investigated by Quebec's Verificatrice générale), the CDP officially switched from a multi-objective mandate to one that put the burden of all investment decisions on the expected return. Its three fundamental values are now stated as "la performance financière... l'imputabilité... et la transparence". ${ }^{19}$ The new mandate means that the CDP will have to forego some investments that may have helped with, say, regional development in Quebec. But they will also make it much more difficult for CDP managers to justify bad (or even corrupt) investment decisions by pointing to intangible non-financial benefits. There is no reason in principle why social democrats and even nationalists cannot rally behind this new policy: rarely is it in the national interest to squander the pensions of public employees.

These lessons from public management should also lead supporters of a strong CSR programme to think about how senior managers in a stakeholder-friendly private-sector firm can be held accountable if they are given the discretion to benefit stakeholder groups as they see fit with little regard to maximizing profits. How could the Board of Directors judge whether the CEO was doing a good job of managing the firm effectively? If the firm's profit margins were lower than its competitors', the CEO could claim that this is because he or she was trying to improve, say, benefits to employees or relations with local communities. Given the relatively loose or "flexible" standards for measuring improvements for various stakeholder groups, a CEO could usually find some ways of indicating that various stakeholders benefited even if shareholders or others suffered. ${ }^{20}$ It would therefore be very difficult for the Board to judge whether even a CEO who is individually committed to the CSR mission of a firm is being successful.

\footnotetext{
${ }^{19}$ See the official communique of the CDP from 3 November 2003, available on their website: http://www.lacaisse.com/LaCaisse/CommuniquePresse/fr/HTML/1617_fr.aspx.

${ }^{20} \mathrm{I}$ have analysed the problem of overly 'flexible' standards of social and ethical auditing in W. Norman and C. MacDonald, 'Getting to the Bottom of "Triple Bottom Line", Business Ethics Quarterly 14/2, 2004, pp. 243-262.
} 
But then consider the case of a CEO who is not deeply committed to a CSR mission but pretends to be in order to exploit the lack of accountability within the stakeholder-friendly firm. (In the agency theory this is known as the moral hazard of 'adverse selection', where lazy or corrupt agents select tasks where it will be difficult for the principal to monitor them.) This could lead to management that exhibits both the inefficiency of old-school SOEs with the corruption and internal fraud of Enron. I know of nowhere in the literature on stakeholder theory and CSR where theorists or advocates seriously deal with the possibility of a firm with a CSR mission being run by a CEO more committed to his own interests than to those of the stakeholders. But designing a system without envisaging this possibility is like recommending a political system that could only be run by a saint. As political philosophers as different as John Stuart Mill and Immanuel Kant have warned: when selecting among governance systems it is better to take the one that would produce good results even if it were run by devils.

\section{CONCLUSION}

In the language of modern management, this means designing a system of governance in which it will be obvious to the Board of Directors if their CEO is incompetent or corrupt. This is the biggest challenge for supporters of CSR in post-Enron era. Incompetent or corrupt managers do not tend to produce sustainable, socially responsible results. I have suggested that advocates of socially responsible business should take seriously the way a focus on profitability facilitates the accountability of senior managers. The challenge, then, is to find innovative ways to make socially responsible business practices more profitable. Fortunately, there are firms in almost every sector of business - from ice cream and cosmetics retailers to forestry and oil companies - that have demonstrated how this can be done.

Now nothing in my analysis so far suggests that this is the only way to secure the sustainable accountability of senior management in a stakeholder-friendly firm. The most basic lesson in my argument is that when stakeholder theorists reject (on various normative grounds, including justice and fairness) the priority of shareholders, they also jettison the principal mechanism for holding senior managers accountable to someone - anyone - besides themselves. It is a version of the common counsel not to throw out the baby (good governance) with the bathwater (neglect of stakeholders). So at the very least, stakeholder theorists have to think seriously about how they will replace this governance function. I have also not argued that it is in principle impossible to have good governance in a context where managers are asked to attain multiple objectives. Obviously, in various ways managers are expected to achieve multiple objectives all the time. Nevertheless, the "bottom line" provides a kind of "common currency" and "reality check" for measuring success and efficiency that has been exceedingly hard to replicate in various departures from the standard model of shareholder-focused capitalism. Of course, just as poorly managed SOEs provide a cautionary tale for stakeholder theorists, so too might well managed SOEs (and yes, there have been some!) provide positive models for combining multi-stakeholder mandates and managerial accountability. To finish with another hackneyed metaphor: stakeholder theorists 
may not have to reinvent the wheel (if successful SOEs and profitable CSR firms have governance structures that can be copied), but nor should they naively rely on wheel designs that have systematically failed to bear the load on bumpy roads. 